\title{
DEVELOPMENT OF ENVIRONMENTAL MANAGEMENT ACCOUNTING AND EMAS OVER TIME
}

\author{
P. Ptáčková Mísařová
}

Received: December 13, 2011

\begin{abstract}
PTÁČKOVÁ MÍSAŘOVÁ, P.: Development of environmental management accounting and EMAS over time. Acta univ. agric. et silvic. Mendel. Brun., 2012, LX, No. 4, pp. 307-318

Environmental management accounting (EMA) is a system that collects, records, evaluates and transmits information about environmentally induced financial impacts and environmental impacts of the given system. In 2006 and 2010 there were two questionnaire surveys. The first survey was carried out under the resolution of grant, which was funded by the Internal Grant Agency of the Mendel University of Agriculture and Forestry in Brno, No. 68/2006, entitled "Development of the EMAS and environmental management accounting in the Czech Republic". The second evaluated questionnaire survey was conducted in the study, which was made in connection with solution of the thesis of author's article. Group of 25 companies that had validated EMAS during the first questionnaire survey was subjected to a survey. The second questionnaire survey was carried out in the same companies in order to make evaluation of development over time. The aim of this paper is to create coherent conclusion about firms that had or have validated EMAS system and use a voluntary instrument EMA in its corporate practice. Partial aim is to evaluate the development of validated organizations and 'sites' with EMAS in time in EU countries. EMAS is a system of management of company and audits in terms of environmental protection. This system is applied within the European Union.
\end{abstract}

environmental management accounting, EMAS, EMA, questionnaire survey

The issue of environmental protection has become frequently discussed not only in the Czech Republic, but especially within the European Union. Enterprises in their decision-making processes must take into account the impacts of their business activities on the environment. Businesses today can no longer look only to their profits, regardless of how their business affects the neighborhood. Environmental management accounting (EMA) is a voluntary tool to protect the environment.

The article compared the data obtained in the two questionnaire surveys. The first questionnaire survey (research No. 1) was carried out under the resolution of grant, which was funded by the Internal Grant Agency of the Mendel University of Agriculture and Forestry in Brno, No. 68/2006, entitled "Development of the EMS and environmental management accounting in the Czech Republic".
The second evaluated questionnaire survey (research No. 2) took place in the study, which was made in connection with solution of thesis of author's article.

Organization needs especially good environmental data for its operation, management and decision making in the environmental field. Environmental management accounting (EMA) is concerned with identifying, collecting, estimations, analysis, reporting and especially with the transfer of quality environmental indicators for both surroundings of organization and management of the organization. EMA integrates two basic building blocks of sustainable development - environment and economy.

Information obtained from the EMA can be used by company management to support decisionmaking processes. Information provided by functional EMA improves the quality of decisionmaking processes. Information from the EMA in the 
long term, that provide information related to the environment are important for the management of organization. Information on past development and also future-oriented information are important. Top management is working mainly with information on environmental investment costs and revenues, with the calculations of life cycle and target calculations. Information on actual results of implemented investment projects are also subject of interest of top management. Information from the EMA system are also used for support of its decision-making processes, in the field of research and development associated with the effects of corporate activities, products and services on the environment.

The aim of the work is, based on analysis of questionnaire surveys, which took place in the research No. 1 and No. 2, to evaluate the development in companies with validated EMAS in terms of environmental management accounting in their business. Partial aim is to evaluate the development of registered organizations and "sites" in EU countries over time.

\section{MATERIAL AND METHODS}

In this work there are applied methods of scientific work leading to the fulfillment of objectives of this work. Primary data was obtained in research No. 1 and No. 2 by questionnaire survey. The questionnaire survey was conducted by sending questionnaires via email to selected organizations. This is a quick and most environmentally friendly way of questioning. Basic statistical methods were used for the evaluation of questionnaires.

In order to achieve partial aim method of analysis of the state of individual EU states was used, the method of description was used to describe the state and trends, and the method of comparison was used to compare and evaluate the situation in the individual EU states. Graphs and tables are used to demonstrate a transparent evaluation.

\section{RESULTS}

EMAS (2010a), or Eco-Management and Audit Scheme (System of management business and audits in terms of environmental protection) is a system that is applied within the European Union.

This system came into force in April 1995 on the basis of Council Regulation (EC) No. 1836/1993 of July 1993 and was primarily intended for the organizations from production (industrial) sector. An organization must meet the criteria established by this program to be a member of the EMAS program and also to be included in the relevant national register.

In the Czech Republic EMAS program was established under Government Resolution of the Czech Republic No. 466/1998 on approval of the National Program of implementation of system of management business and audits in terms of environmental protection.
On 16 July 2008 the European Commission adopted a package of documents concerning sustainable consumption and production, which included also a proposal on Regulation of the European Parliament and Council Regulation (EC) on voluntary participation of organizations in the system of environmental management and audit scheme (EMAS). This proposal was, as stated Ruzicka (2009), discussed by European Parliament in the course of January to April 2008 and subsequently approved by Council. Existing regulation for EMAS program, which is given by Regulation No. 761/2001, was replaced by new regulation since 1 January 2010.

The main objectives of the revision according to the European Parliament and Council Regulation (EC) No. 1221/2009 of 25 November 2009 on voluntary participation by organizations in the system of Community for eco-management of businesses and audits scheme (EMAS), declared at the beginning of the document are:

- increasing the number of organizations involved in the Program;

- recognition of EMAS as the highest standard (benchmark) for the implementation of environmental management systems;

- enable organizations that have implemented environmental management system according to other standards (e.g. ISO 14001, national standards), an easy transition to EMAS;

- require organizations registered in EMAS, to take into account environmental criteria when selecting their suppliers and service providers.

Basic requirements, for organizations that wish to register, remain same in the draft of new regulation as in Regulation No. 761/2001.

On the basis of EMAS organizations can also provide key indicators of its activity, which can be used not only for the internal needs of the organization, but also for example for environmental reporting.

Organizations of all economic activities (according to NACE) should determine, as stated Hřebíček, Soukopová, Štencl, Trenz (201la), the environmental KPIs and, moreover, the organizations of the selected economic activities should choose additional environmental KPIs according to the significant environmental aspects. To do this, the internal (possibly external) environmental audit of EMS of organization can be used, on the basis of which the organization management will propose the additional KPIs in cooperation with an auditor or verifier of EMAS.

The great importance is attributed, as stated Hřebíček, Soukopová, Štencl, Trenz (2011b), to the defining of KPIs in the economic, environmental, social and governance areas for specified economic activities (NACE) with subsequent measurement of sustainable development.

The following charts, which are completed by tables, show the development of number of 
Register of organization with EMAS system on 30 June 2011

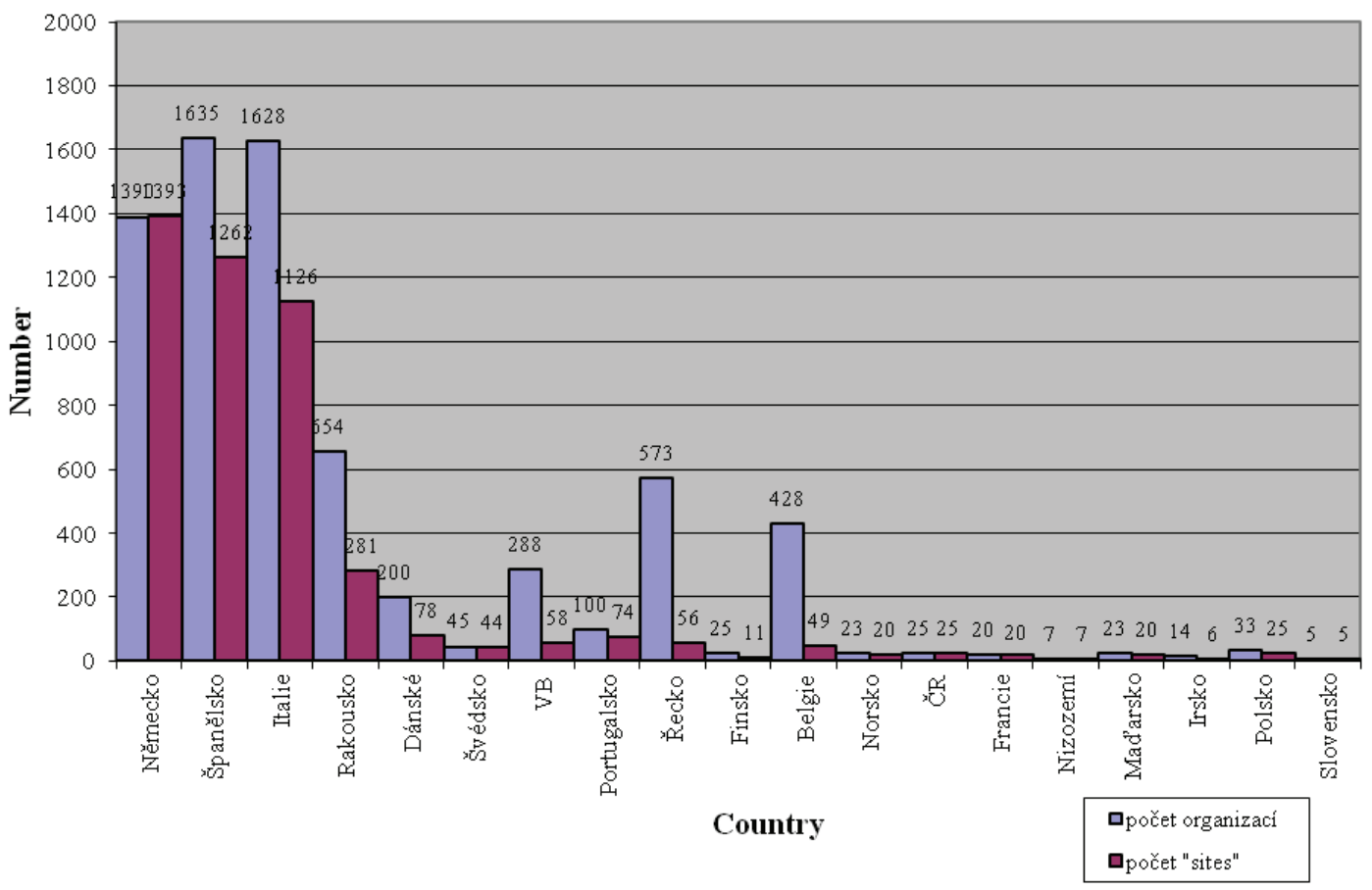

1: Organization with EMAS system on 30 June 2011

Source: own work, processed according to information [cit. 2011-07-29] available on the Web: http:// ec.europa.eu/environment/emas/documents/articles_en.htm\#statistic

I: Register of organizations with EMAS system on 30 June 2011

\begin{tabular}{lcclcc}
\hline \multicolumn{1}{c}{ Country } & $\begin{array}{c}\text { Number of } \\
\text { organizations }\end{array}$ & Number of "sites" & \multicolumn{1}{c}{ Country } & $\begin{array}{c}\text { Number of } \\
\text { organizations }\end{array}$ & Number of "sites" \\
\hline Germany & 1390 & 1393 & Netherlands & 7 & 7 \\
Spain & 1635 & 1262 & Hungary & 23 & 20 \\
Italy & 1628 & 1126 & Ireland & 14 & 6 \\
Austria & 654 & 281 & Poland & 33 & 5 \\
Denmark & 200 & 78 & Slovakia & 5 & 5 \\
Sweden & 45 & 44 & Estonia & 5 & 3 \\
Great Britain & 288 & 58 & Luxembourg & 1 & 1 \\
Portugal & 100 & 74 & Malta & 1 & 1 \\
Greece & 573 & 56 & Slovenian & 7 & 3 \\
Finland & 25 & 11 & Bulgaria & 0 & 0 \\
Belgium & 428 & 49 & Cyprus & 5 & 5 \\
Norway & 23 & 20 & Latvia & 0 & 0 \\
CR & 25 & 25 & Lithuania & 7 & 5 \\
France & 20 & 20 & Romania & 6 & 4 \\
\hline
\end{tabular}

Source: own work, processed according to information [cit. 2011-07-29] available on the Web: http://ec.europa.eu/ environment/emas/documents/articles_en.htm\#statistic

organizations and "sites" with EMAS validation in individual years.

Charts 4 and 5 give total economic development of organizations and "sites" with validated EMAS.

Fig. 4 and 5 show very different developments in individual countries. If we look at Figure 4, there is a significant increase in the number of validation of organizations according to EMAS on 30 June
2011 such in Spain, Italy, Austria, Denmark, Great Britain, Greece or Belgium. There is no significant decrease in any of the mentioned state, but a smaller decline occurred for example in Sweden. In this context it should be noted that EMAS III is in effect from 1 January 2010. In this context we can say that businesses are finding the changes included in the EMAS III. as positive, because there was not 


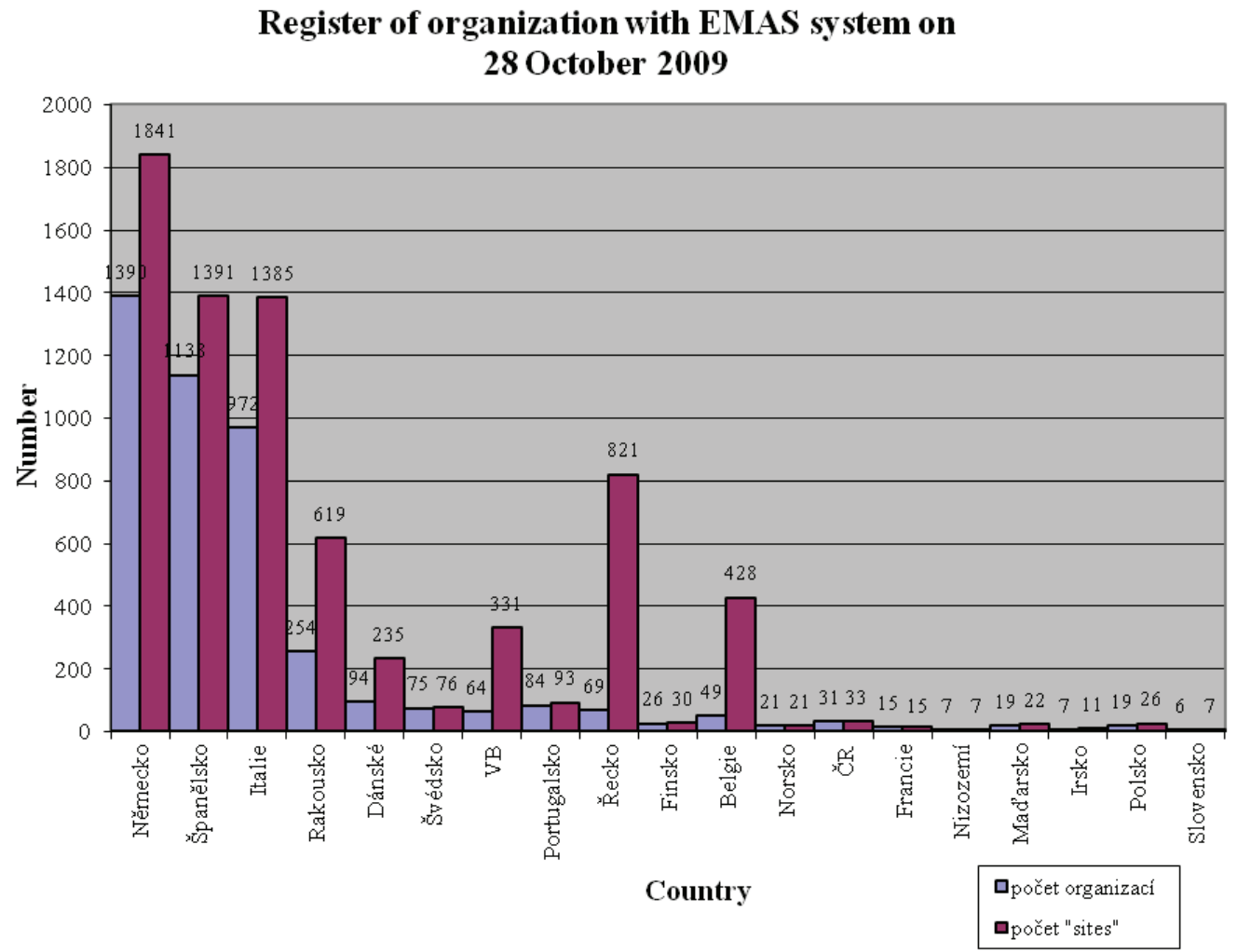

2: Organization with EMAS system on 28 October 2009

Source: own work, processed according to information [cit. 2011-02-13] available on the Web: <http:// ec.europa.eu/environment/emas/pdf/5_5articles_en.pdf>

II: Register of organizations with EMAS system on 28 October 2009

\begin{tabular}{lcclcc}
\hline \multicolumn{1}{c}{ Country } & $\begin{array}{c}\text { Number of } \\
\text { organizations }\end{array}$ & Number of "sites" & Country & $\begin{array}{c}\text { Number of } \\
\text { organizations }\end{array}$ & Number of "sites" \\
\hline Germany & 1390 & 1841 & Netherlands & 7 & 7 \\
Spain & 1138 & 1391 & Hungary & 19 & 22 \\
Italy & 972 & 1385 & Ireland & 7 & 11 \\
Austria & 254 & 619 & Poland & 19 & 26 \\
Denmark & 94 & 235 & Slovakia & 6 & 7 \\
Sweden & 75 & 76 & Estonia & 2 & 4 \\
Great Britain & 64 & 331 & Luxembourg & 2 & 4 \\
Portugal & 84 & 93 & Malta & 1 & 1 \\
Greece & 69 & 821 & Slovenian & 2 & 6 \\
Finland & 26 & 30 & Bulgaria & 0 & 0 \\
Belgium & 49 & 428 & Cyprus & 5 & 5 \\
Norway & 21 & 21 & Latvia & 0 & 0 \\
CR & 31 & 33 & Lithuania & 6 & 9 \\
France & 15 & 15 & Romania & 3 & 5 \\
\hline
\end{tabular}

Source: own work, processed according to information [cit. 2011-02-13] available on the Web: http://ec.europa.eu/ environment/emas/pdf/5_5articles_en.pdf>

a significant decline in registrations on 30 June 2011 in any country, but there was a significant increase in number of registrations in many states.

In the Czech Republic there was a decrease in the number of validated companies from 31 to 25 on 30 June 2011. In the Czech Republic there is generally very small amount of validated companies compared to countries of Western Europe.

Figure 5 shows summarized results for the number of validated "sites". One organization may have validated more "sites" - plants, branches, etc. 


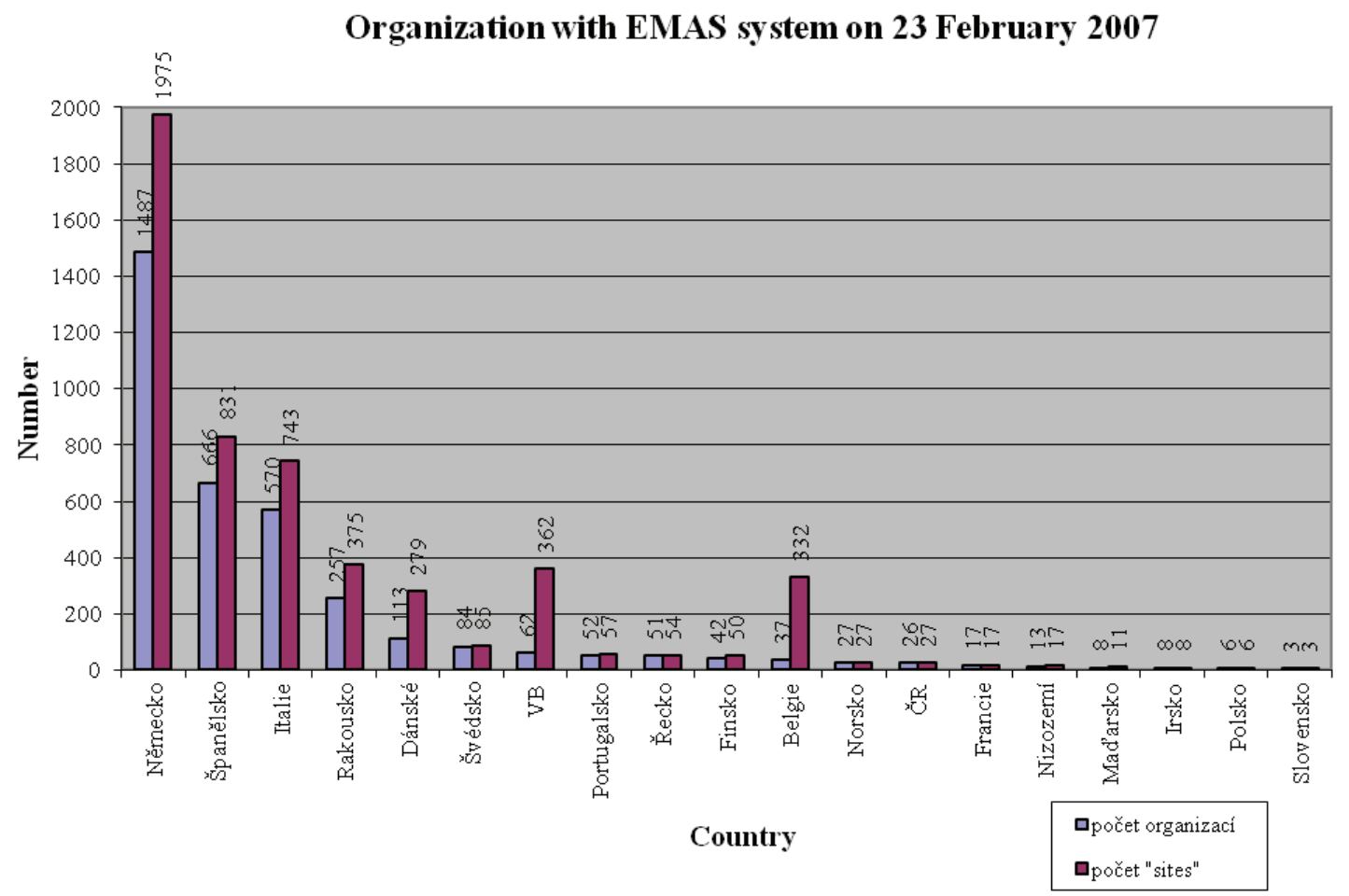

3: Organization with EMAS system on 23 February 2007

Source: own work, processed according to information [cit. 2007-05-03] available on the Web: 〈http:// ec.europa.eu/environment/emas/documents/articles_en.htm\#statistic>

III: Register of organizations with EMAS system on 23 February 2007

\begin{tabular}{lcclcc}
\hline \multicolumn{1}{c}{ Country } & $\begin{array}{c}\text { Number of } \\
\text { organizations }\end{array}$ & Number of "sites" & Country & $\begin{array}{c}\text { Number of } \\
\text { organizations }\end{array}$ & $\begin{array}{c}\text { Number of } \\
\text { "sites" }\end{array}$ \\
\hline Germany & 1487 & 1975 & Netherlands & 13 & 17 \\
Spain & 666 & 831 & Hungary & 8 & 11 \\
Italy & 570 & 743 & Ireland & 8 & 8 \\
Austria & 257 & 375 & Poland & 6 & 6 \\
Denmark & 113 & 279 & Slovakia & 3 & 3 \\
Sweden & 84 & 85 & Estonia & 2 & 2 \\
Great Britain & 62 & 362 & Luxembourg & 1 & 1 \\
Portugal & 52 & 57 & Malta & 1 & 1 \\
Greece & 51 & 54 & Slovenian & 1 & 0 \\
Finland & 42 & 50 & Bulgaria & 0 & 0 \\
Belgium & 37 & 332 & Cyprus & 0 & 0 \\
Norway & 27 & 27 & Latvia & 0 & 0 \\
CR & 26 & 27 & Lithuania & 0 & 0 \\
France & 17 & 17 & Romania & 0 & 1 \\
\hline
\end{tabular}

Source: own work, processed according to information [cit. 2007-05-03] available on the Web: <http://ec.europa.eu/ environment/emas/documents/articles_en.htm\#statistic>

Therefore number of organizations and number of "sites" can vary in the individual states.

The numbers really vary and also the development in each year is different. Number of 'sites' decreased in all states on 30 June 2011. Since the re-validation is also costly, companies reduce the number of validations of "sites" (plants, branches, factories, etc.) and are willing to continue to maintain only a validation of the company. That is the mason why there is a reduction in the number of "sites".

Only company OHL ZS, a.s. has more plants validated in the Czech Republic, and it still holds the validation of all three plants.

The problem deals with a number ranomovaných authors. Of note is worth publication Petrosillo, De Marco Botta, Comoglio (2012), who deal with self- 
Development of the number of organizations with EMAS over time

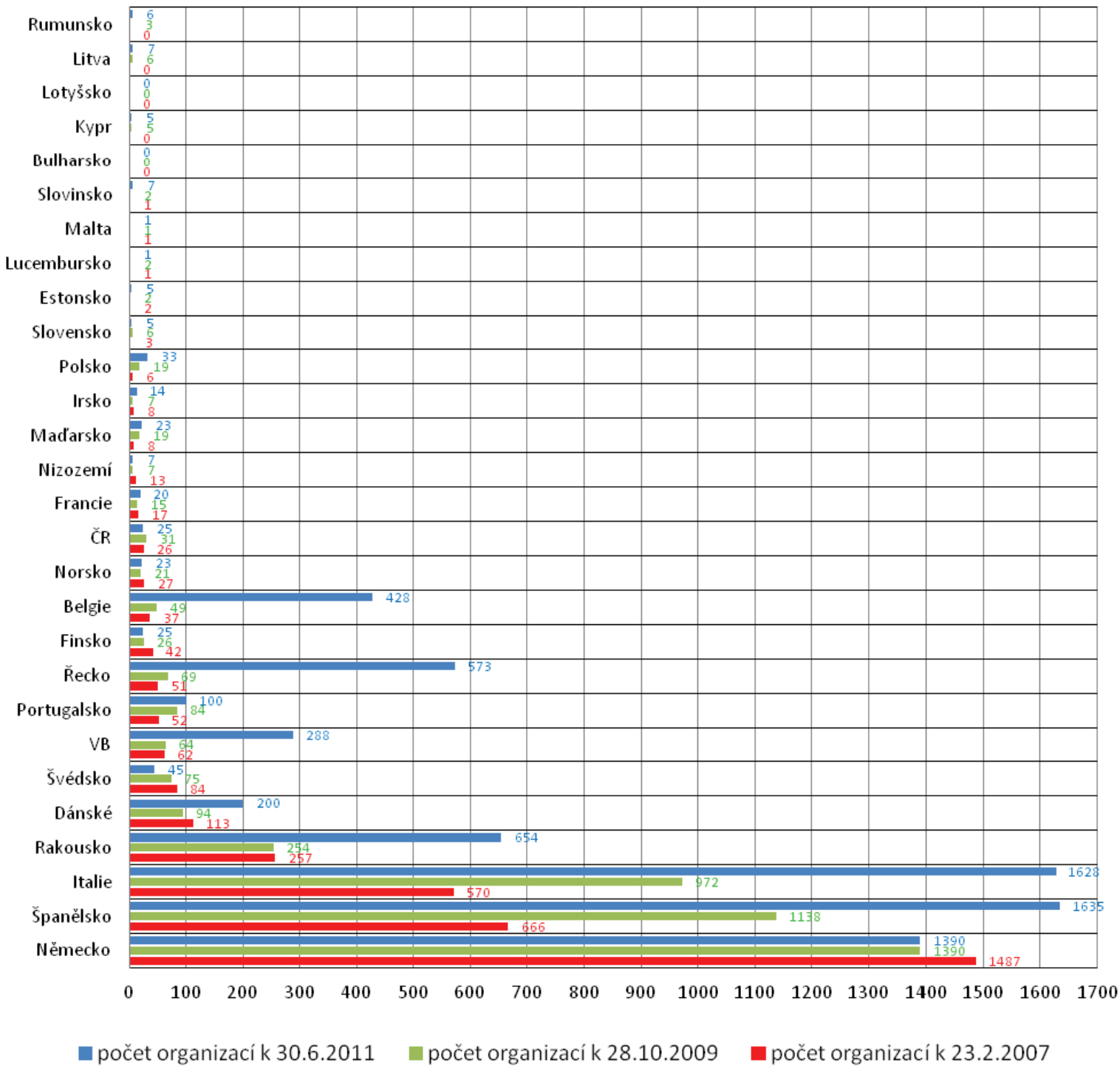

4: Development of the number of organizations with EMAS over time

Source: own work, processed according to information available on the Web: <http://ec.europa.eu/environment/emas/ registration/sites_en.htm>

realization EMAS (Eco-Management and Audit Scheme) to local authorities in Italy. To do this all the EMAS registered public authorities in Italy have been contacted to obtain a copy of their most recent validated environmental statements. Finally work notes that analyzed the environmental statements (75\% response rate) deal with a high number of environmental aspects and refer to a wide range of activities carried out by the local authorities. The set of indicators demonstrates that registered local authorities have already enough information for the purpose of complying with the new EMAS III core indicators. On the contrary, EMAS III does not properly cover the several environmental issues and impacts faced by local authorities, so that a different, wider and more specific framework is needed for their environmental performance evaluation.
As a result of this study, a set of 13 indicators has been proposed, based on those already in use by local authorities and on those used by the European Environment Agency for environmental assessments.

\section{Environmental management accounting}

Environmental management accounting (hereafter EMA) is, as stated Hyršlová (2004), defined according to the International Federation of Accountants (IFAC, 1998) as "management of environmental performance and economic performance through the development and implementation of appropriate, related to the environment, accounting systems and procedures. It is obvious that both financial and non-financial aspects are the subject of interest of EMA. 
Development of the number of "sites" with EMAS over time

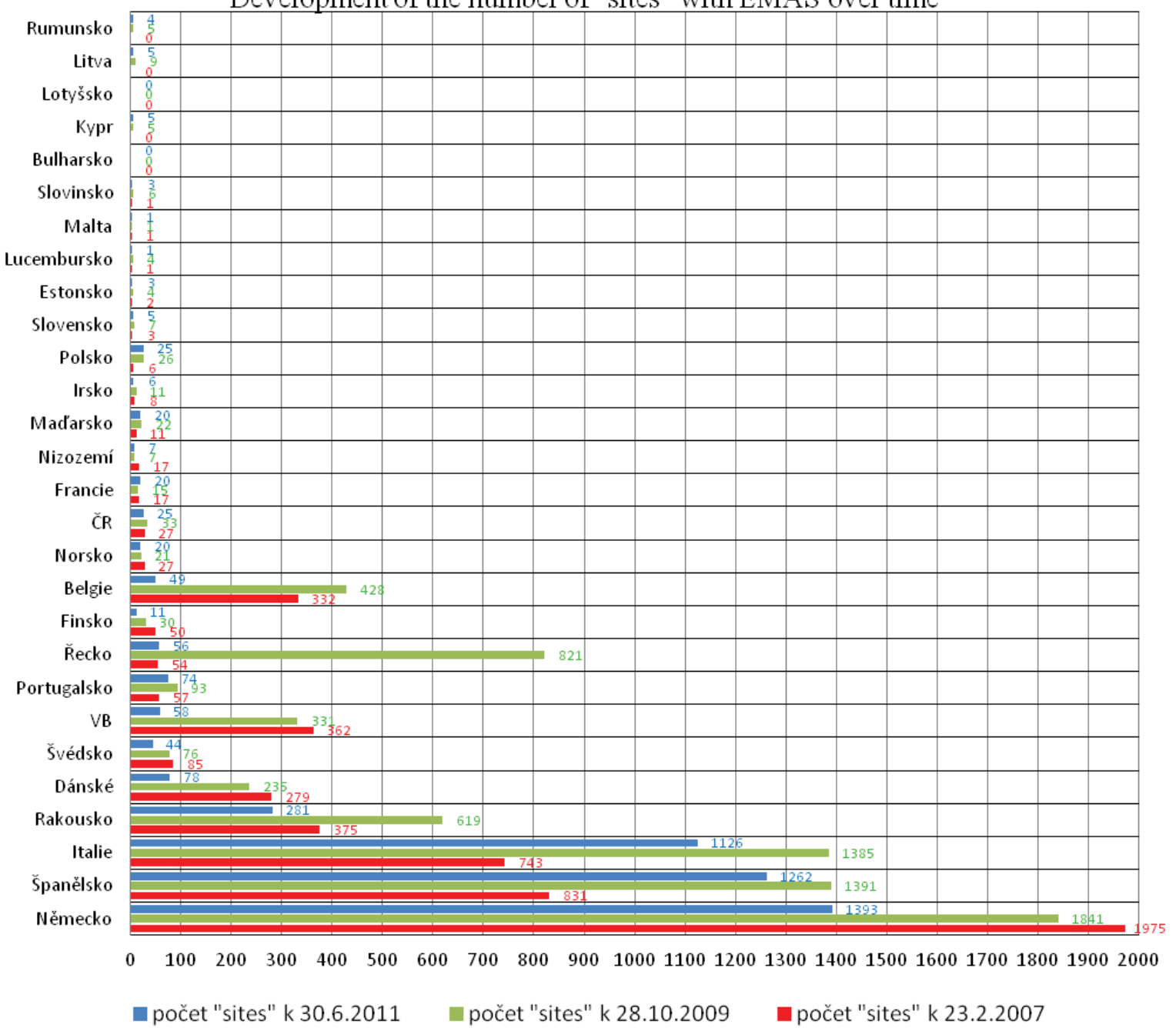

5: Development of the number of "sites" with EMAS over time

Source: own work, processed according to information available on the Web: <http://ec.europa.eu/environment/emas/ registration/sites_en.htm>

EMA covers the identification, collection, estimations, analysis, reporting and transfer of:

- information on material and energy flows,

- information on environmental costs and

- other quantified information, which are the basis for decision-making within the organization.

EMA integrates two basic building blocks of sustainable development - environment and economics - and so, as these aspects appear in the internal decision-making processes of the organization.

\section{EMA in companies with EMAS}

The author of this publication is a researcher of two projects in companies with validated EMAS program.

Research no. 1 was funded by the Internal Grant Agency of the Mendel University of Agriculture and Forestry in Brno under No. 68/2006, entitled
"Development of the EMS and environmental management accounting in the Czech Republic".

Questionnaire survey, which was supported by dial-up interviews with responsible personnel of enterprises and personal visits in selected companies was used as primary information of the grant.

All organizations in the Czech Republic, which had at the time of research validated environmental management system according to the European program EMAS was addressed in frame of questionnaire survey. It was about 25 companies from entire country.

Research No. 2 was conducted within the frame of processing thesis, when an extensive questionnaire, divided into three phases and also in three parts, was created.

Detailed analysis of individual phases and parts of questionnaire survey can be found in the author's thesis (Mísařová, 2010a). 
Subsequently only data obtained from the third phase of questioning (the second part of the questionnaire) will be processed and evaluated.

\section{The third phase of the survey}

Organizations that participated in questionnaire survey in research No. 1 were contacted in the third phase. During the research no. 1 it was all organizations that had validated EMAS in the time of the survey. Now the same group of organizations was addressed, regardless of whether they have now or not validated EMAS, from the reason of possible comparison and evaluation over time. Questionnaire in electronic form, accompanying letter and information about EMA were sent to all these organizations.

\section{2.part of questionnaire}

This part was aimed at finding the primary data from the EMA. Due to the fact that also organizations that did not have knowledge about what is EMA could be questioned a brief summary of what is EMA was sent to all respondents. If they did not work with a voluntary instrument in the form of EMA in the given company, so this part has been terminated in the question no. 12 (other questions were not relevant for such respondent) and they go to Part 3, where there was collected data on barriers of the implementation of EMA.

If in the opinion of the respondent they use EMA in their activities and decisions in the organization, other questions in this section are devoted to the form, scope and experience with EMA in the given organization. The aim was to find out:

- what form the EMA has in the given organization,

- what data the company receives from EMA,

- how are the data monitored in long term,

- whether the data are evaluated,

- for what purposes are inquired,

- who uses information from EMA,

- in what units is the information provided,

- how EMA is today (some time after implementation) perceived,

- additional partial information about given organization and its approach to the EMA.

25 companies were addressed in both surveys. For further processing the file of companies is reduced by 2 , because the company OHL ZS, a.s. had EMAS validated for three plants. After consultation with the responsible worker of company OHL ZS, a.s. it was settled that the returned questionnaire is for the entire organization and not only for a plant. In the research No. 1, there was a feedback of 17 questionnaires, from the total number of 23 sent questionnaires, which represents a return of $74 \%$.

In research, No. 2, 14 questionnaires returned, the return was therefore $61 \%$. The return was thus reduced by 3 questionnaires. It is necessary to remove another 3 questionnaires, from the given 14 returned questionnaires, because these three organizations responded, that from the reasons of time they will not fill in a questionnaire. The difference in the processed questionnaires therefore is 6 i.e. $26 \%$.

Compared to individual companies that returned and completed questionnaires, it was found out that only one company responded in research No. 2 and in research No. 1 did not return the questionnaire. Otherwise they are the same companies in research no. 2 that already answered in the questionnaire survey in research No. 1 .

The subject of both surveys was first to determine whether the company practice is familiar with the concept of environmental accounting. Research no. 1 showed that as much as 95\% of respondents said that they were familiar with the concept of environmental accounting. In research No. 2, 91\% of respondents said that they have already known the concept of environmental management accounting. Only one respondent replied that he is not familiar with the concept of EMA. This business was from the category of small enterprises (10-49 employees) with a turnover shifting it between medium-sized enterprises (turnover greater than 30 and equal to 100 million CZK). According to both surveys, we can say that the concept of environmental management accounting is known in corporate practice among companies with validated EMAS.

Also environmental costs and benefits from a friendly approach to the environment are concepts which, according to findings of both studies. are known in the business practice.

In research No. 2 only 4 companies reported that they use a voluntary instrument of environmental behavior in the form of environmental management accounting, which is $36 \%$. In research No. 1 this fact was reported by 9 companies, which is 53\%. From given fact it can be concluded that companies used a voluntary instrument EMA and subsequently they ceased to use this tool. This conclusion would not be completely correct without stating the fact that in the research No. 2 there were totally addressed 164 companies in the questionnaire survey, and because they were companies from different industries, companies with validated EMAS or only with certified ISO 14000, cover letter explaining the nature and definition of EMA and essence of EMA management was sent to all companies. Due to this fact it can also be said that after deeper awareness that was provided to companies in the research No. 2, some companies have ceased to call their system as environmental management accounting, and therefore the answer was negative.

While in research No. 2 all companies declare that their form of EMA is in frame of financial accounting, where they have only determined some analytical accounts in accounting schedule, so in research no. 1 there were more diverse possible solutions of EMA forms. Some companies have stated that they have EMA in frame of internal accounting and not just financial accounting and 4 companies indicated that they monitor these data independently, outside the 


\section{To whom is the information from EMAS intended}
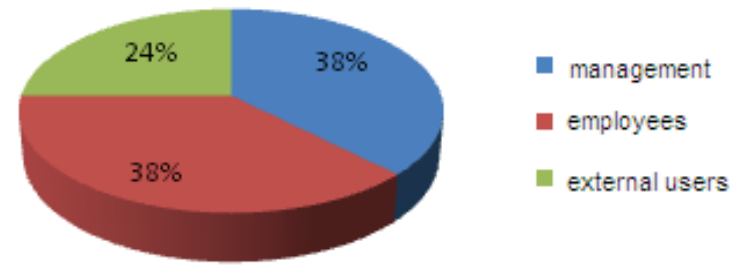

6: To whom is the information intended Source: own work [Mísařová, 2011]

\section{Reasons for the implementation of EMA}

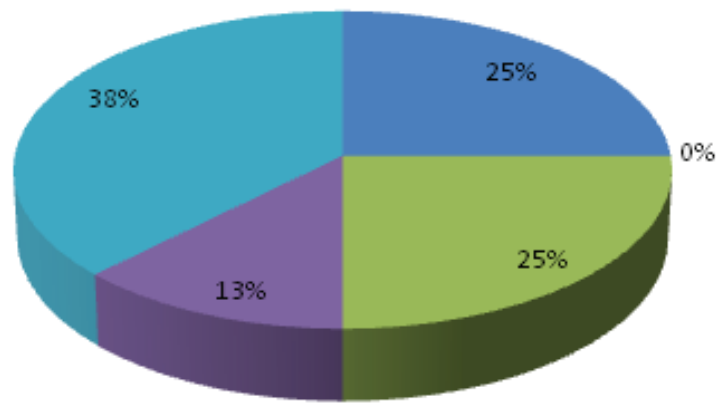

- pressure of laws and standards

- requirement from external entity outside your company

cost savings

- improved market position, competitive advantage

a. continuous interest in environmental protection

7: Reasons for the implementation of EMA

Source: own work [Mísařová, 2011]

system of accounting. Based on an interview in these companies it was found out that it is for example in the form of various tables. Only one business from those that responded to the question admitted that identifies the data only on request, i.e. one time, as a result of solving a problem.

All businesses from research No. 2 identically show that they monitor their environmental costs and benefits for the business as a whole. They do not monitor them in a line of products, services nor processes. Research No. 1 shows that more than half of companies monitors and evaluates environmental costs and benefits for the business as a whole. Significant proportions (30\%) of companies monitor these costs and benefits in the line of departments. Some companies also said a combination of individual possibilities of monitoring. This monitoring along the line of departments or in line of process applies only to large enterprises in terms of turnover (turnover of more than 100 million) and large (250 and more employees) and medium (50-249 employees) in terms of number of employees. These results are logic and we could expect confirmed results. The more detailed monitoring and evaluation of environmental costs and benefits, the more administrative and time burden on businesses. It can afford only large companies that have enough staff and funding. Companies must also consider the benefits of a more detailed level of detection and monitoring of these data. Benefits in the monitoring of environmental costs and benefits are undeniable for all businesses, but every company must consider whether the costs to obtain such information are too high for it.

Both studies clearly showed that information obtained from EMA helps improve decision-making in the business. This is one of the tasks of EMA - to help to improve decision-making in businesses through better information of decision makers.

Research No. 2 was extended to include other issues important to the overall image of EMA in companies with validated EMAS - to who is information obtained from EMA intended and the reasons for the implementation of EMA.

Finding out what the most benefit from the introduction of EMA perception respondents was the last very important question. The answer was quite clear, it is getting better information about the effects on the environment.

According to respondents, information from EMA is used equally by the representation of management in its decision, by the staff in their work and also by surroundings of enterprise through environmental reporting. All the companies provide information in monetary units and one company said that the information is also provided in physical units.

\section{SUMMARY}

The aim of the work, based on analysis of questionnaire surveys, which took place in frame of the research No. 1 and No. 2, is to evaluate developments in companies with validated EMAS in terms of environmental management accounting in their business. A partial goal is to evaluate the development of registered organizations and "sites" in EU countries over time.

EMAS is a system of management business and audits in terms of environmental protection. This system is applied within the European Union. Environmental management accounting (EMA) is concerned with identifying, collection, estimations, analysis, reporting, and especially the transfer of quality environmental indicators both for surroundings of organization and management of the 
organization. EMA is a voluntary tool to protect the environment. EMA integrates two basic building blocks of sustainable development - environment and economy.

On the basis of EMAS organizations can also provide key indicators of its activity, which can be used not only for the internal needs of the organization, but also for example for environmental reporting. The article compared the data obtained in the two questionnaire surveys. The first questionnaire survey (research No. 1) was carried out under the grant, which was funded by the Internal Grant Agency of the Mendel University of Agriculture and Forestry in Brno, No. 68/2006, entitled "Development of the EMS and environmental management accounting in the CR".

The second evaluated questionnaire survey (research No. 2) took place in the study, which was made in connection with solution of the thesis of author's article.

They were contacted organizations (participated in the research questionnaire No. 1) regardless of whether or not they have now validated EMAS, and there is potential for comparison and evaluation over time. The questionnaire, the covering letter and information about EMA (all in electronic form) were sent to all these organizations.

25 companies were addressed in both surveys. For further processing the file of companies is reduced by 2, because the company OHL ZS, a.s. had EMAS validated for three plants. After consultation with the responsible worker of company OHL ZS, a.s. it was settled that the returned questionnaire is for the entire organization and not only for a plant. In the research no. 1, there was a feedback of 17 questionnaires, from the total number of 23 sent questionnaires, which represents a return of 74\%.

The work was also to analyze and subsequent assessment of the situation from the perspective of EMAS to the entire European Union.

In countries like Spain, Italy, Austria, Denmark, Great Britain, Greece, Belgium has been marked significant increase in the number of validation of organizations according to EMAS on 30 June 2011. There was not a significant decrease in any of the states, but there was a smaller decline e.g. in Sweden. In this context it should be noted that EMAS III is in effect from 1 January 2010. In this context we can say that businesses are finding the changes included in the EMAS III. as positive, because there was not a significant decline in registrations on 30 June 2011 in any country, vice versa there was a significant increase in number of registrations in many states.

In the Czech Republic there was a decrease in the number of validated companies from 31 to 25 on 30 June 2011. In the Czech Republic there is generally very small amount of validated companies compared to countries of Western Europe.

Main objective was achieved by the evaluation of results from research no. 1 and research No. 2 with regard to the development of environmental management accounting in companies with validated EMAS over time.

The results introduced in the paper are part of the research project No. 6215648904 "The Czech economy in the process of integration and globalization and the development of agrarian sector and service sector in the new conditions of European integrated market".

\section{REFERENCES}

EMAS [online]. European Commision, 2010a [cit. 2010-02-13]. Dostupné na www: <http:// ec.europa.eu/environment/emas/index_en.htm>

EMAS [online]. European Commision, 2010b [cit. 2011-07-29]. Dostupné na www: <http:// ec.europa.eu/environment/emas/documents/ articles_en.htm\#statistic >.

EMAS [online]. European Commision, 2010c [cit. 2010-02-13]. Dostupné na www: <http:// ec.europa.eu/environment/emas/index_en.htm>.

EMAS [online]. European Commision, 2007 [cit. 2007-05-03]. Dostupné na www: <http:// ec.europa.eu/environment/emas/documents/ articles_en.htm\#statistic $>$.

HYRŠLOVÁ, J., 2004: Environmentální manažerské účetnictví jako nástroj podnikového managementu. Slovenská technická universita $\mathrm{v}$ Bratislavě, Materiálovotechnologická fakulta v Trnavě, 162 s. Habilitační práce.

HŘEBÍČEK, J., SOUKOPOVÁ, J., ŠTENCL, M., TRENZ, O., 201la: Corporate Key Performance
Indicators for Environmental Management and Reporting. Acta Universitatis Agriculturae et Silviculturae Mendeliande Brunensis. 2011. sv. 59, č. 2, s. 99-107. ISSN 1211-8516.

HŘEBÍČEK, J., SOUKOPOVÁ, J., ŠTENCL, M., TRENZ, O., 201lb: Integration of economic, environmental, social and corporate governance performance and reporting in enterprises. Acta Universitatis Agriculturae et Silviculturae Mendelianae Brunensis. 2011. sv. 2011, č. 7, s. 157-166. ISSN 1211-8516.

IFAC (International Federation of Accountants) 1998 Environmental Management in Organizations. The Role of Management Accounting. New York, Financial and Management Committee, International Federation of Accountants, Study 6, March 1998.

MÍSAŘOVÁ, P., 201l: Aktuální situace EMAv podnicích $s$ validovaným In Enterprise and Competitive Environment 2011. 1. vyd. Bučovice: Martin Stř̌́ž Publishing, 2011, s. 132-146. ISBN 978-80-8710640-2. 
MÍSAŘOVÁ, P., 2010a: Bariéry a prínosy environmentálního manažerského účetnictví. [online] Mendelova univerzita v Brně, Provozně ekonomická fakulta. Disertační práce 148 s. [cit. 2010-10-10]. Dostupné na www: <http:// is.mendelu.cz/lide/clovek.pl?id=438;zalozka=7;st udium $=19671>$.

MÍSAŘOVÁ, P., 2010b: Bariéry zavádèní environmentálního manažerského účetnictví do praxe podniku. Acta Universitatis Agriculturae et Silviculturae Mendelianae Brunensis. 2010b. č. 3, s. 145-157. ISSN 1211-8516.

Nařízení Evropského parlamentu a Rady (ES) č. 1221/2009 ze dne 25. listopadu 2009 o dobrovolné účasti organizací v systému Společenství pro environmentální řízení podniků a auditu (EMAS) [online]. 2009 [cit. 2010-06-13]. Dostupné na www: <http://eur-lex.europa.eu/LexUriServ/ LexUriServ.do?uri=OJ:L:2009:342:0001:01:CS:H TML>.

PETROSIO, I., DE MARCO, A., OTTA, S., COMOGLIO, C., 2012: EMAS in local authorities: Suitable indicators in adoptng environmental management systems. Ecological Indicators. 2012. No. 13 (1), pp. 263-274.

RƯŽIČKA, P., 2009: Revize program EMAS. In: Účetnictví a reporting udržitelného rozvoje na mikroekonomické a makroekonomické úrovni. 1. vyd. Praha: Linde nakladatelství s. r. o., s. 133134. ISBN 978-80-86131-82-5. 
